І. О. Філонік, Л. Ф. Заморуєва, А. А. Кисла

Дніпропетровський національний університет ім. Олеся Гончара

\title{
СКЛАД ЛІПІДІВ У НАСІННІ ГІРКОКАШТАНА ЗВИЧАЙНОГО, КЛЕНА ГОСТРОЛИСТОГО ТА ДУБА ЗВИЧАЙНОГО В УМОВАХ ДНІПРОПЕТРОВСЬКОГО РЕГІОНУ
}

\begin{abstract}
Досліджено показники ліпідного обміну (рівень загальних ліпідів та їх склад, компонентний склад вільних жирних кислот) у насінні гіркокаштана звичайного, клена гостролистого та дуба звичайного з різних ділянок техногенного забруднення м. Дніпропетровськ. Виявлено зниження вмісту загальних ліпідів у насінні гіркокаштана звичайного та клена гостролистого з білышості промислових територій та збільшення вмісту ліпідів у насінні дуба звичайного; відмічено редукцію фракції вільних жирних кислот у насінні трьох видів дерев. Вивчені зміни показників вмісту та складу ліпідів у деревних культур свідчать про їх адаптивні можливості при антропогенному забрудненні у промисловому регіоні.
\end{abstract}

\section{И. А. Филоник, Л. Ф. Заморуева, А. А. Кислая \\ Днепропетровский наииональный университет им. Олеся Гончара \\ СОСТАВ ЛИПИДОВ В СЕМЕНАХ ГОРЬКОКАШТАНА ОБЫЧНОГО, КЛЕНА ОСТРОЛИСТОГО И ДУБА ОБЫЧНОГО В УСЛОВИЯХ ДНЕПРОПЕТРОВСКОГО РЕГИОНА}

\begin{abstract}
Изучены показатели липидного обмена (уровень общих липидов и их состав, компонентный состав свободных жирных кислот) в семенах горькокаштана обыкновенного, клена остролистого и дуба обычного с различных площадок техногенного загрязнения г. Днепропетровск. Выявлено снижение содержания общих липидов в семенах горькокаштана обыкновенного и клена остролистого с большинства промышленных территорий и увеличение общих липидов в семенах дуба обыкновенного; отмечена редукция фракции свободных жирных кислот в семенах трех видов деревьев. Найденные изменения показателей содержания и состава липидов в древесных культурах свидетельствуют об их адаптивных возможностях при антропогенном загрязнении в промышленном регионе.
\end{abstract}

I. O. Filonik, L. F. Zamorueva, A. A. Kisla

Oles' Honchar Dnipropetrovsk National University

\section{COMPOSITION OF LIPIDS IN CHESTNUT, MAPLE AND OAK SEEDS IN CONDITIONS OF THE DNIPROPETROVSK CITY}

Parameters of lipids metabolism such as a level of total lipids and their composition, and composition of free fatty acids in the chestnut, maple and oak seeds from several polluted sites of Dnipropetrovsk were investigated. The decrease of the content of total lipids in chestnut and maple seeds and increase in the oak seeds under conditions of industrial pollution have been found. The reduction of free fatty acids fraction in seeds of all studied trees is recorded. The revealed changes in the content of total lipids and their composition in trees' seeds may reflect the adaptation possibilities to anthropogenic pollution in industrial region.

(C) І. О. Філонік, Л. Ф. Заморуєва, А. А. Кисла, 2010 


\section{Вступ}

Висока концентрація промислових підприємств на урбанізованих територіях, особливо в Дніпропетровському регіоні, призводить до значного техногенного забруднення навколишнього середовища. Поряд із промисловими підприємствами та автомагістралями періодично утворюються високі концентрації токсичних сполук, що спричинює комплексне забруднення атмосфери, поверхневих i грунтових вод, погіршення фізико-хімічних властивостей грунтів, завдає вагомої шкоди природним рослинним екосистемам і штучним насадженням [3].

У великих промислових центрах домінуючим чинником, що впливає на інтенсивність ростових процесів рослин, стає забруднення середовища токсичними сполуками промислового походження, що підсилює або зменшує дію всіх інших факторів. Різні за хімічним складом емісії промислових виробництв і вихлопні гази автотранспорту викликають подібні симптоми пошкоджень рослин [9]. Стійкість деревних рослин до зовнішніх антропогенних чинників значною мірою визначається біоекологічними особливостями виду, умовами росту та розвитку, ступенем генетичної здатності видів до адаптації в умовах навколишнього середовища, що постійно змінюється [11].

Високий сорбційний ефект до забруднення важкими металами відмічено у деревних культур: черемхи, тополі корейської, осики, клена дрібнолистого та прирічкового. Каштан посівний був стійкішим за інші лісові види до забруднення сіркою, він показав кращі результати на грунтах середнього механічного складу, але на глинистих грунтах його ріст був помірним, відмічено високий вміст сірки в його листі на всіх ділянках [12]. Клен явір, тополя канадська проявляли високу стійкість до вихлопних газів, у той час, як клен гостролистий і каштан кінський звичайний дуже чутливі до їх дії [10]. При накопиченні важких металів різними органами сіянців каштана кінського та дуба звичайного відбувалось підвищення вмісту вільних амінокислот у листі та корінні обох видів, яке було суттєвішим у менш стійкого каштана кінського.

Дія сірчаного газу на каштан кінський i дуб звичайний приводила до пригнічення біосинтезу білка у каштана та активації його у стійкого дуба. Показано, що під впливом емісії промислових підприємств у листі берези повислої та гледичії звичайної відбувалась активація гідролітичних ферментів, яка могла бути наслідком руйнування клітин у рослин [9]. В умовах промплощадок коксохімічних підприємств виявлено пошкодження листя клена гостролистого некрозом (від 30 до $40 \%$ ). Під впливом важких металів відбувалось інгібування синтезу хлорофілу, яке часто візуально виражалось у вигляді хлорозу [14].

На територіях, які зазнають впливу емісій промислових підприємств, важливо використовувати породи, перспективні для створення у степу штучного лісу [2]. Вони повинні бути стійкі до того чи іншого типу інгредієнтів промислових викидів і мати високий репродуктивний потенціал, що необхідно для формування стійких і тривало існуючих екосистем. Показники плодоношення деревних рослин можна використовувати у моніторингу забруднення i стану деревних фітоценозів захисних зон підприємств важкої металургії [4].

Насіння містить різну кількість поживних речовин у формі вуглеводів, білків і жирів. Характерною особливістю зрілого насіння каштана кінського звичайного було те, що по завершенні дозрівання в них не формувались білкові тіла і містилась незначна кількість запасних ліпідів, які розміщувались уздовж плазмалеми. Методом тонкошарової хроматографії в ліпідній фракції зародкових осей зрілого насіння Aesculus hippocastanum виявлено значні кількості вільних поліненасичених жирних кислот - 
лінолевої та полілінолевої ( $R f 0,49)$. Встановлено наявність двох речовин $R f 0,93$ $R f 0,82$, що поглинали ультрафіолет. Можна припустити, що це ефіри окиснених похідних поліненасичених жирних кислот [1].

У зав'язях каштана звичайного (I, контроль) і з морфологічними змінами плодів (II, порожня шкірка) визначали вміст гормонів і поживних речовин через 5-105 діб після цвітіння. Вміст відновних цукрів, крохмалю, білка, амінокислот у зав'язях (I) підвищувався та тримався на високому рівні в указаний період, а у II варіанті - знижувався та зберігався на низькому рівні. Вважають, що аномальний розвиток плодів у II варіанті пов'язаний із зазначеними змінами вмісту та співвідношення фітогормонів і вмісту поживних речовин. Під впливом важких металів відбуваються структурні зміни біомембран рослин [16]. Дія кадмію викликала різкі зміни ліпідного складу мембран, де в усіх класах ліпідів знайдено підвищення кількості пальмітинової кислоти, а вміст лінолевої та ліноленової кислот був зменшений [12]. Наслідком цього могли бути зміни проникності біомембран, що поряд з інгібуванням мембранних ферментів, можливо, викликало зміни іонного балансу в цитоплазмі. Кадмій і свинець викликали зміни ліпідного складу мембран тилакоїдів [13; 15], а також розширення тилакоїдних мембран, що, на думку деяких авторів, $\epsilon$ результатом беспосереднього впливу кадмію на розвиток пластид [14].

Рослини використовують різні механізми для адаптації в умовах антропогенного навантаження за дії полютантів, які необхідно досліджувати, щоб зменшити рівень порушень у рослинному організмі, а саме у деревних культур.

Мета роботи - оцінити вміст і склад ліпідів, вільних жирних кислот у насінні клена гостролистого, каштана кінського та дуба звичайного з різних промплощадок і автомагістралей Дніпропетровська для з'ясування впливу техногенного забруднення на стан деревних рослин.

\section{Матеріал і методи досліджень}

Досліджували вплив техногенного навантаження у Дніпропетровському регіоні (2009 р.) на фізіолого-біохімічні показники ліпідного обміну у насінні гіркокаштана звичайного, клена гостролистого та дуба звичайного; проведено моніторинг цих показників деревних рослин із промислових зон і автомагістралей м. Дніпропетровськ.

Виділення сумарних ліпідів проводили за модифікованою методикою Блайя Дайєра [8]. Тонкошарову хроматографію загальних ліпідів, їх поділ на основні фракції 3 кількісним денситометруванням проводили за [5; 7]. Компонентний склад вільних жирних кислот визначали методом газорідинної хроматографії на хроматографі «Хром-5» (Чехія) за [7]. Одержані експериментальні дані статистично оброблені за [6], біологічні досліди та біохімічні аналізи проводили у триразовій повторності, у таблицях наведені середні дані.

\section{Результати та їх обговорення}

Ліпіди відіграють важливу роль у рослинному організмі, виконують запасні та захисні функції, ферменти ліпідного обміну ліпази, які розщеплюють жири на вільні жирні кислоти та тригліцериди, сприяють накопиченню вільних жирних кислот, склад яких змінюється під впливом стресових факторів. Тому вивчення вмісту та фракційного складу ліпідів, а також компонентного складу вільних жирних кислот у насінні деревних культур із різних ділянок техногенного навантаження $є$ актуальним $i$ необхідним у наш час. У насінні гіркокаштана звичайного виявлено підвищення вмісту загальних ліпідів на деяких ділянках (парк ім. Гагаріна, парк ім. Шевченка, район 
річкового порту), тоді як у насінні клена гостролистого збільшення вмісту загальних ліпідів спостерігалось і поблизу заводів (металургійний завод ім. Леніна, ОАО “Дніпрошина", парк ім. Шевченка). У насінні дуба звичайного виявлено підвищення вмісту загальних ліпідів (до $11 \%$ ) на території ОАО “Дніпрошина”. Зареєстровано зниження вмісту загальних ліпідів у насінні гіркокаштана звичайного та клена гостролистого на ділянках антропогенного навантаження поблизу промислових підприємств (завод пресів, завод ім. Карла Лібкнехта) та перехрестя доріг (від 7 до 29 \%) (табл. 1).

Вміст загальних ліпідів у насінні гіркокаштана звичайного, клена гостролистого Таблиия 1 та дуба звичайного, зібраному на промислових ділянках Дніпропетровського регіону

\begin{tabular}{|c|c|c|}
\hline \multirow{2}{*}{ Зразок, район відбору } & \multicolumn{2}{|c|}{ Вміст загальних ліпідів, \% } \\
\hline & відношення до наважки & відношення до контролю \\
\hline $\begin{array}{l}\text { Насіння гіркокаштана звичайного: } \\
\text { - ботанічний сад, контроль }\end{array}$ & $7,0^{*}$ & 100 \\
\hline - парк ім. Гагаріна & 9,0 & 129 \\
\hline - парк ім. Шевченка & 8,0 & 114 \\
\hline - перехрестя доріг & 6,0 & 86 \\
\hline - проспект ім. Карла Маркса & 5,0 & 71 \\
\hline - район ЦУМу & 6,5 & 93 \\
\hline - район річкового порту & 7,0 & 100 \\
\hline -завод пресів & 6,5 & 93 \\
\hline - завод ім. Карла Лібкнехта & 6,0 & 86 \\
\hline - завод ім. Леніна & 5,5 & 79 \\
\hline - OAO “Дніпрошина” & 6,0 & 86 \\
\hline $\begin{array}{l}\text { Насіння клена гостролистого: } \\
\text { - ботанічний сад, контроль }\end{array}$ & 14,5 & 100 \\
\hline - парк ім. Гагаріна & 11,5 & 79 \\
\hline - парк ім. Шевченка & 16,0 & 110 \\
\hline - перехрестя доріг & 13,5 & 93 \\
\hline - проспект ім. Карла Маркса & 13,0 & 90 \\
\hline - район річкового порту & 10,5 & 72 \\
\hline - завод пресів & 14,5 & 100 \\
\hline - завод Леніна & 18,0 & 124 \\
\hline - ОАО “Дніпрошина” & 16,0 & 110 \\
\hline $\begin{array}{l}\text { Насіння дуба звичайного: } \\
\text { - ботанічний сад, контроль }\end{array}$ & 4,5 & 100 \\
\hline - парк ім. Шевченка & 4,5 & 100 \\
\hline - OAO “Дніпрошина” & 5,0 & 111 \\
\hline - м. Синельникове & 4,5 & 100 \\
\hline
\end{tabular}

Знайдене збільшення вмісту ліпідів у насінні досліджуваних деревних рослин на забруднених ділянках можна розглядати як адаптивну реакцію рослин на дію техногенного забруднення навколишнього середовища.

При вивченні фракційного складу загальних ліпідів виявлено редукцію вмісту вільних жирних кислот у насінні трьох досліджуваних рослин; зниження вмісту фосфоліпідів у відібраних зразках насіння клена гостролистого та гіркокаштана звичайного з різних ділянок техногенного забруднення. Фосфоліпіди - одні з основних компонентів біомембран клітин рослинних організмів, тому зменшення їх вмісту може свідчити про пошкодження біомембран деревних рослин за дії стресових факторів. Крім цього, у насінні клена гостролистого та гіркокаштана звичайного відмічалось підвищення вмісту ефірів стеринів і фракції стеринів, тоді як у насінні дуба звичайного вміст стеринів дещо знижувався (табл. 2). 
Компонентний склад загальних ліпідів у насінні гіркокаштана звичайного, клена гостролистого та дуба звичайного, зібраному на промислових ділянках м. Дніпропетровськ

\begin{tabular}{|l|c|c|c|c|c|c|}
\hline \multirow{2}{*}{ Зразок, район відбору } & \multicolumn{5}{|c|}{ Вміст фракцій загальних ліпідів, \% } \\
\cline { 2 - 7 } Насіння гіркокаштана звичайного: & ФЛ & ДГ & С & ВЖК & ТГ & ЕС \\
\hline - ботанічний сад, контроль & 19,93 & 16,15 & 15,46 & 16,16 & 16,84 & 15,46 \\
\hline - парк ім. Гагаріна & 19,08 & 18,75 & 18,09 & 15,79 & 16,12 & 12,17 \\
\hline - парк ім. Шевченка & 17,05 & 15,91 & 16,29 & 17,42 & 17,80 & 15,53 \\
\hline - перехрестя доріг & 17,85 & 16,48 & 16,11 & 17,23 & 16,48 & 15,85 \\
\hline - проспект ім. Карла Маркса & 17,42 & 17,81 & 17,42 & 15,90 & 16,29 & 15,16 \\
\hline - район ЦУМу & 18,92 & 17,76 & 16,60 & 15,83 & 15,06 & 15,83 \\
\hline - район річкового порту & 20,15 & 17,45 & 17,44 & 15,12 & 15,50 & 14,34 \\
\hline - завод пресів & 19,05 & 17,46 & 16,67 & 16,27 & 15,08 & 15,47 \\
\hline - завод ім. Карла Лібкнехта & 17,79 & 17,39 & 16,60 & 15,81 & 16,20 & 16,21 \\
\hline - завод ім. Леніна & 19,12 & 17,13 & 16,33 & 15,94 & 15,94 & 15,54 \\
\hline - ОАО “Дніпрошина” & 19,84 & 17,91 & 16,73 & 15,95 & 15,17 & 14,40 \\
\hline Насіння клена гостролистого: & & & & & & \\
- ботанічний сад, контроль & 20,10 & 16,97 & 17,43 & 16,97 & 15,14 & 13,39 \\
\hline - парк ім. Гагаріна & 19,45 & 18,18 & 17,72 & 17,27 & 14,09 & 13,29 \\
\hline - парк ім. Шевченка & 19,48 & 18,57 & 17,61 & 16,67 & 14,76 & 12,91 \\
\hline - перехрестя доріг & 19,09 & 18,18 & 17,23 & 16,27 & 14,83 & 14,40 \\
\hline - проспект ім. Карла Маркса & 20,21 & 17,68 & 17,17 & 16,16 & 14,65 & 14,13 \\
\hline - район річкового порту & 19,70 & 18,69 & 18,18 & 15,66 & 14,14 & 13,63 \\
\hline - завод пресів & 20,98 & 18,32 & 15,71 & 16,25 & 14,66 & 14,08 \\
\hline - завод ім. Леніна & 19,50 & 17,00 & 17,50 & 16,00 & 15,00 & 15,00 \\
\hline - ОАО “Дніпрошина” & 19,87 & 17,48 & 16,02 & 16,50 & 15,05 & 15,08 \\
\hline Насіння дуба звичайного: & & & & & & \\
- ботанічний сад, контроль & 16,47 & 17,10 & 18,41 & 19,07 & 15,79 & 13,16 \\
\hline - парк ім. Шевченка & 17,26 & 16,61 & 18,32 & 18,66 & 15,93 & 13,22 \\
\hline - ОАО “Дніпрошина” & 17,59 & 17,26 & 18,24 & 17,59 & 16,62 & 12,70 \\
\hline - м. Синельникове & 18,03 & 17,71 & 18,03 & 17,38 & 15,41 & 13,44 \\
\hline
\end{tabular}

Примітка: ФЛ - фосфоліпіди, ДГ - дигліцериди, С - стерини, ВЖК - вільні жирні кислоти, ТГ - тригліцериди, ЕС-ефіри стеринів.

За складом вільних жирних кислот відмічено зростання вмісту олеїнової кислоти $\mathrm{C}_{18: 1}$ у насінні всіх трьох деревних культур із більшості промислових ділянок. У насінні гіркокаштана звичайного виявлено підвищення вмісту $\mathrm{C}_{18: 1}$ (на 5-11 \%: завод ім. Карла Лібкнехта, завод ім. Леніна, ОАО «Дніпрошина», парк ім. Гагаріна), тоді як у насінні клена гостролистого збільшення вмісту $\mathrm{C}_{18: 1}$ спостерігалось (на 2-7 \%) на території заводу пресів та заводу ім. Леніна і зменшення на 7 \% поблизу ОАО «Дніпрошина». У насінні дуба звичайного підвищення вмісту $\mathrm{C}_{18: 1}$ (на 11-17 \%) на ділянках ОАО «Дніпрошина» та м. Синельникове. Вміст лінолевої та ліноленової кислот зменшувався в усіх деревних культурах (на 1-16\%) (завод ім. Леніна, завод ім. Карла Лібкнехта, завод пресів, ОАО «Дніпрошина», парк ім. Гагаріна, м. Синельникове), за винятком насіння дуба звичайного з ділянки парку ім. Шевченка, де виявлено підвищення вмісту цих ненасичених жирних кислот (табл. 3). Підвищення сумарного рівня ненасичених жирних кислот свідчило про адаптивні процеси у різних деревних культур до дії техногенного пресу.

Зменшення вмісту загальних ліпідів, стеринів і фосфоліпідів під впливом техногенного пресу може свідчити про пошкодження захисних функцій деревних рослин на 
рівні організму та на мембранному рівні 3 промислово-забруднених ділянок м. Дніпропетровськ.

Таблиия 3

Компонентний склад вільних жирних кислот у насінні гіркокаштана звичайного, клена гостролистого та дуба звичайного, зібраному на промислових ділянках Дніпропетровського регіону

\begin{tabular}{|c|c|c|c|c|c|c|c|c|c|c|c|}
\hline \multirow{2}{*}{$\begin{array}{c}\text { Зразок, } \\
\text { район відбору }\end{array}$} & \multicolumn{11}{|c|}{ Вміст вільних жирних кислот, \% } \\
\hline & $\begin{array}{c}\mathrm{C}_{12: 0^{-}} \\
\mathrm{C}_{15: 0} \\
\end{array}$ & $\mathrm{C}_{16: 1}$ & $\mathrm{C}_{16: 0}$ & $\mathrm{C}_{17: 0}$ & $\mathrm{C}_{18: 1}$ & $\mathrm{C}_{18: 0}$ & $\mathrm{C}_{18: 2,3}$ & $\begin{array}{c}\mathrm{C}_{19: 0-} \\
\mathrm{C}_{25: 0} \\
\end{array}$ & $\Sigma_{\text {ненас. }}$ & $\Sigma_{\text {нас, }}$ & $\begin{array}{c}\text { не- } \\
\text { нас. }\end{array}$ \\
\hline $\begin{array}{l}\text { Насіння гіркокаштана: } \\
\text { - ботанічний сад, контроль }\end{array}$ & 0,84 & 0,08 & 8,74 & 1,35 & 51,35 & 4,72 & 21,30 & 11,62 & 72,73 & 27,27 & 2,67 \\
\hline - парк ім. Гагаріна & 0,32 & 0,04 & 7,91 & 0,14 & 62,60 & 5,09 & 13,30 & 9,15 & 75,94 & 24,06 & 3,16 \\
\hline - завод пресів & 0,69 & 0,04 & 16,06 & 1,97 & 47,51 & 5,16 & 18,68 & 7,28 & 66,23 & 33,77 & 1,96 \\
\hline - завод ім. Карла Лібкнехта & 0,18 & 0,04 & 8,55 & 0,24 & 63,59 & 4,75 & 7,92 & 11,98 & 71,55 & 28,45 & 2,51 \\
\hline - завод ім. Леніна & 0,43 & 0,03 & 8,62 & 0,46 & 59,18 & 6,91 & 9,20 & 13,79 & 68,41 & 31,59 & 2,17 \\
\hline -ОАО “Дніпрошина” & 0,36 & 0,01 & 8,95 & 0,73 & 57,81 & 6,90 & 14,24 & 8,97 & 72,06 & 27,94 & 2,58 \\
\hline $\begin{array}{l}\text { Насіння клена гостролистого: } \\
\text { - ботанічний сад, контроль }\end{array}$ & 0,07 & 0,01 & 7,51 & 0,80 & 45,91 & 3,20 & 22,83 & 16,32 & 68,75 & 31,25 & 2,2 \\
\hline - парк ім. Гагаріна & 0,04 & 0,01 & 7,55 & 0,56 & 45,47 & 3,65 & 22,17 & 17,28 & 67,65 & 32,35 & 2,1 \\
\hline -завод пресів & 0,07 & 0,01 & 7,41 & 0,44 & 47,63 & 4,12 & 16,46 & 19,21 & 64,10 & 35,90 & 1,8 \\
\hline - завод ім. Леніна & 0,07 & 0,01 & 8,80 & 0,58 & 52,85 & 2,88 & 14,14 & 17,46 & 67,0 & 33,0 & 2,0 \\
\hline - OAО “Дніпрошина” & 1,20 & 0,01 & 15,91 & 2,88 & 38,74 & 16,35 & 12,81 & 9,04 & 51,56 & 48,44 & 1,1 \\
\hline $\begin{array}{l}\text { Насіння дуба звичайного: } \\
\text { - ботанічний сад, контроль }\end{array}$ & 0,12 & 0,01 & 12,35 & 1,85 & 49,26 & 4,63 & 27,41 & 4,28 & 76,68 & 23,32 & 3,3 \\
\hline - парк ім. Шевченка & 0,17 & 0,01 & 15,68 & 4,02 & 31,07 & 1,76 & 43,40 & 3,78 & 74,48 & 25,52 & 2,9 \\
\hline - ОАО “Дніпрошина” & 0,26 & 0,01 & 16,04 & 1,29 & 66,93 & 1,96 & 11,05 & 2,42 & 77,99 & 22,01 & 3,5 \\
\hline - м. Синельникове & 0,10 & 0,01 & 15,27 & 3,00 & 61,70 & 2,57 & 15,78 & 1,55 & 77,49 & 22,51 & 3,4 \\
\hline
\end{tabular}

Зниження рівня вільних жирних кислот за дії техногенного навантаження може свідчити також про прискорення реакцій перекисного окиснення ліпідів у процесах адаптації рослин до забруднення навколишнього середовища в умовах тенденції потепління клімату.

\section{Висновки}

Виявлено підвищення вмісту загальних ліпідів у насінні гіркокаштана звичайного 3 ділянок парку ім. Гагаріна, парку ім. Шевченка та зниження у забруднених зонах поблизу заводів (завод пресів, завод ім. Леніна, завод ім. Карла Лібкнехта, ОАО “Дніпрошина”) та автомагістралей. У насінні клена гостролистого відмічене зменшення показників вмісту сумарних ліпідів майже на всіх техногенно-забруднених ділянках, проте поблизу заводів (металургійний завод ім. Леніна, ОАО “Дніпрошина” та парк ім. Шевченка) спостерігалося його збільшення. У насінні дуба звичайного виявлене підвищення вмісту загальних ліпідів на території ОАО “Дніпрошина”.

Відмічено редукцію вмісту вільних жирних кислот у насінні трьох досліджуваних рослин, зниження вмісту фосфоліпідів у відібраних зразках насіння клена гостролистого та гіркокаштана звичайного та підвищення їх у насінні дуба звичайного 3 різних ділянок техногенного забруднення.

При дослідженні компонентного складу вільних жирних кислот виявлено зниження коефіцієнта ненасиченості жирних кислот (сума ненасичених / сума насичених) у насінні гіркокаштана звичайного та клена гостролистого, але підвищення цього коєфіцієнта у насінні дуба звичайного. 
Виявлено зміни вмісту сумарних ліпідів, їх фракційного складу та компонентного складу вільних жирних кислот у насінні гіркокаштана звичайного, клена гостролистого та дуба звичайного з різних ділянок техногенного забруднення Дніпропетровського регіону, що свідчать про адаптивні процеси в усіх видах деревних рослин до промислового навантаження та можуть бути використані для оцінки стану дерев на забруднених територіях. За цими показниками дуб звичайний - найстійкіша, а клен - найменш стійка і найчутливіша до техногенного забруднення культура.

\section{Бібліографічні посилання}

1. Бабенко Л. М. Структурно-функціональні особливості проростаючого насіння Aesculus hippocastanum L. / Л. М. Бабенко, Г. Г. Мартин, Л. І. Мусатенко // Доповіді НАН України. 2002. - № 6. - C. 163-166.

2. Безсонова В. П. Насіннева продуктивність деревних рослин в умовах забруднення довкілля хлором та його сполуками / В. П. Безсонова, С. О. Яковлєва-Носар // Укр. ботан. журн. - 2007. T. 64, № 1. - С. 115-121.

3. Бессонова В. П. Цитофизиологические эффекты воздействия тяжелых металлов на рост и развитие растений. - Запорожье : ЗГУ, 1999. - 380 с.

4. Бессонова В. П. Влияние загрязнения природной среды на плодоношение древесных растений / В. П. Бессонова, Т. И. Юсипова // Лесн. хоз-во. - 1998. - С. 39-40.

5. Вплив гербіцидного фону на загальний ліпідний склад та фосфоліпіди в зерні кукурудзи гібриду Дніпровський 284 / Л. Ф. Заморуєва, В. М. Глибока, І. О. Філонік, О. М. Вінниченко // Вісник Дніпропетр. ун-ту, Біологія. Екологія. - 2002. - Вип. 10, т. 1. - С. 194-197.

6. Доспехов Б. А. Методика полевого опыта. - М. : Агрохимиздат, 1985. - 351 с.

7. жирные кислоты поверхностных липидов зерна кукурузы обычных и высоколизиновых форм / А. Н. Винниченко, Н. И. Штеменко, Л. Ф. Заморуева и др. // Химия природных соединений. - 1990. - № 3. - С. 262-264.

8. Кейтс М. Техника липидологии. - М. : Мир, 1975. - 320 с.

9. Коршиков И. И. Адаптация растений к условиям техногенно загрязненной среды. - К. : Наукова думка, 1996. - $238 \mathrm{c}$.

10. Коршиков И. И. Взаимодействие растений с техногенно загрязненной средой. - К. : Наукова думка, 1995. - 190 с.

11. Коршиков И. И. Популяционно-генетические проблемы дендро-техногенной интродукции / И. И. Коршиков, Н. С. Терлыга, С. А. Бычков. - Донецк : Лебедь, 2002. - 326 с.

12. Cadmium and copper-induced changus in tomato membrane lipids / O. Ouariti, N. Boussama, M. Zarrouk et al. // Phitochemistry. - 1997. - Vol. 45. - P. 1343-1350.

13. Effect of lead on the lipid metabolism in spinach leaves and thylakoid membranes / K. L. Stefanov, S. D. Pandev, K. A. Seizova et al. // Biol. Plant. - 1995. - Vol. 37. - P. 251-256.

14. Ernst W. H. O. Effects of heavy metals in plants at the cellular and organismic level// Ecotoxicology. Ecological fundamentals, chemical exposure and biological effects / Eds. G. Schuurmana, B. Markert. - Heidelberg : Wiley and Sons Inc., 1999. - P. 587-620.

15. Malik D. Lipid composition of thylakoid membranes of cadmium treated wheat seedlings / D. Malik, I. S. Sheoran, R. Singh // Indian J. Biochem. Biophys. - 1992. - Vol. 29. - P. 350-354.

16. Mehard A. A. The role of plasmalemma in metal toleranse in angiosperms // Phisiol. Plant. - 1993. Vol. 88. - P. 191-198.

Надійшла до редколегї̈ 30.09.2010 